\title{
Response of growth and production of potato plants to application of NPK fertilizer
}

\author{
Lydia E A Tulung*, Mirawanty Amin, and Conny N Manoppo
}

Assessment Institute For Agricultural Technology of North Sulawesi, Kampus Pertanian Kalasey

Street, Manado 95013 North Sulawesi

\begin{abstract}
Fertilizer is one of the determining factors for the success of potato cultivation. Various types of fertilizers have been produced, but those that are suitable for regional conditions in North Sulawesi do not yet exist. The decreasing of potato production in North Sulawesi is due to the limited use of quality and certified seeds, as well as inappropriate fertilizer dosages. This research objective was to see the effect of NPK fertilization on the production of Medians potato plants. The research was conducted from August to December 2020, in Rurukan Village, East Tomohon District, Tomohon City, North Sulawesi. The experimental design used was randomized complete block design (RCBD) with seven treatments, namely the NPK fertilizer dosage of $0 \mathrm{~kg} \mathrm{ha}^{-1}\left(\mathrm{P}_{0}\right), 150 \mathrm{~kg} \mathrm{ha}^{-1}\left(\mathrm{P}_{1}\right), 300 \mathrm{~kg} \mathrm{ha}^{-1}\left(\mathrm{P}_{2}\right)$, $450 \mathrm{~kg} \mathrm{ha}^{-1}\left(\mathrm{P}_{3}\right), 600 \mathrm{~kg} \mathrm{ha}^{-1}\left(\mathrm{P}_{4}\right), 750 \mathrm{~kg} \mathrm{ha}^{-1}\left(\mathrm{P}_{5}\right)$ and $900 \mathrm{~kg} \mathrm{ha}^{-1}\left(\mathrm{P}_{6}\right)$. Each treatment was repeated three times and resulting in 21 treatment plots. The results showed that application of NPK fertilizer of $450 \mathrm{~kg} \mathrm{ha}^{-1}$ resulted the highest yields on the components of weight of fresh plant, tuber diameter, and potato productivity.
\end{abstract}

\section{Introduction}

Potato productivity in North Sulawesi is relatively low compared to its potential yield. According to the data of Statistics Indonesia (BPS) in 2020, average potato productivity in North Sulawesi is about 10-15 tons ha- ${ }^{-1}$ [1], on the other hand based on research results of Vegetable Research Centre (Balitsa) in 2018, the potential yield could reach 30-50 tons ha-1. Salwati et al. [2] stated that the maximum potato productivity in Minahasa was 18 tons ha ${ }^{-1}$. During 2018-2020, potato production in North Sulawesi has decreased, from 965,500 Ku to $733,763 \mathrm{Ku}[1]$. The decreasing of potato production was caused by a shortage of harvested area, farmers' behavior in cultivation, and limited quality seeds.

The main factors that determine potato productivity are seeds, fertilizers, labor, and varieties [3]. Some result studies shows that low potato productivity caused by farmers 'poor farming techniques, limited of fertilizer application and the use of inferior seeds [4,5]. In line with this, The poor quality of seeds used by farmers causes low potato production. Farmer commonly use seed the previous crops, which is uncertified seed. These may cause decreasing crop productivity.

\footnotetext{
* Corresponding author: tulung.lydia@gmail.com
} 
The use of superior varieties supported by optimal nutrient availability conditions is expected to increase potato productivity. Optimal nutrient availability can be done with balanced fertilization. Balanced fertilization is one way of cultivation that can be done to increase productivity. Due to unbalanced use and not being managed properly, some nutrients are lost from the soil [6]. Fertilizer application is the best way to increase yield per unit area. NPK fertilizer can increase the yield and quality of potato tubers [7].

Environmental factors are factors which greatly affect plant growth because they affect physiological processes in plants. Plant growth determined by genetic and environmental factors $[8,9]$. The processes that occur in plant development and growth are very complex in the relationship between soil, plants, and climate [2,9]. The interaction between environmental and genetic factors can cause the potato plants to grow and develop well [10].

Potato productivity could be increased by improving cultivation systems, through the application of appropriate and balanced fertilization and the use of superior varieties. According to Kiloes and Puspitasari (2016) [7], the Medians potato is a variety that tolerant of late blight, bacterial and viral wilt, and has good adaptability to tropical climates. This variety is suitable to be developed in Indonesia, especially in North Sulawesi. Median is a high yield variety with the potential yield of 32 tons/ha, and suitable for the needs of the potato chip industry.

NPK fertilizer $(15: 15: 15)$ is one of the NPK fertilizer products that have been widely used by the farmers with a content of Nitrogen (N) 15\%, Phosphorus (P2O5) 15\%, Potassium (K2O) $15 \%$, Sulfur (S) $10 \%$, and a maximum moisture content of $2 \%$. This compound fertilizer is almost completely soluble in water, so the nutrients it contains can be absorbed effectively [11]. Phonska fertilizer is a type of compound fertilizer because it contains evenly distributed nutrients that are needed by plants.

Therefore, it is necessary to do NPK fertilization research on Medians potatoes, to improve and increase potato productivity in North Sulawesi. The research objective was to determine the effect of NPK fertilizer dosage on Median potato production.

\section{Materials and methods}

The experiment was conducted in Rurukan Village, East Tomohon Subdistrict, Tomohon City from August to December 2020. The research location is at an altitude of 1418 meters above sea level with a temperature range of $18^{\circ} \mathrm{C}-30^{\circ} \mathrm{C}$. The material used was $\mathrm{G} 3$ potato Median variety and NPK fertilizer (15:15:15). The experimental design used was a Randomized Complete Block Design (RCBD) with seven treatments, namely the NPK fertilizer doses of $0 \mathrm{~kg} \mathrm{ha}^{-1}$ (P0), $150 \mathrm{~kg} \mathrm{ha}^{-1}$ (P1), $300 \mathrm{~kg} \mathrm{ha}^{-1}$ (P2), $450 \mathrm{~kg} \mathrm{ha}^{-1}$ (P3), $600 \mathrm{~kg}$ $\mathrm{ha}^{-1}$ (P4), $750 \mathrm{~kg} \mathrm{ha}^{-1}$ (P5) and $900 \mathrm{~kg} \mathrm{ha}^{-1}$ (P6). Each treatment was repeated three times, so that there were 21 treatment plots.

The variables observed were plant weight of fresh plant, plant weight of dry plant, number of tubers, tuber diameter, and tuber productivity. All the variables were measured at the age of 32, 62 and 92 days after planting. The diameter of the tubers was measured from the smallest to the largest using a caliper. While the number of tubers, counted all the bulbs contained in one plant population. The data collected were analyzed using analysis of variance (ANOVA), followed by the Duncan test $5 \%$.

\section{Results and discussion}

The results of Duncan's 5\% analysis showed that giving NPK fertilizer at a dose of $0-900$ $\mathrm{kg}\left(\mathrm{P}_{0}-\mathrm{P}_{6}\right)$ gave results that were not significantly different at the age of $92 \mathrm{DAP}$. This means 
the application of NPK fertilizer at the dosage of each treatment does not affect the weight of dry plant and number of Medians potato tubers.

Other production components such as weight of fresh plant and tuber diameter from the analysis of variance (ANOVA) showed the treatment of NPK fertilizer $\mathrm{P}_{0}$ to $\mathrm{P}_{6}$ had a significant effect (Table 1). Duncan's 5\% analysis showed the treatment of fertilizer dosage $\mathrm{P}_{0}$ to $\mathrm{P}_{6}$ had a significant effect on weight of fresh plant and tuber diameter (Table 1).

Table 1. The average of weight of fresh plant, weight of dry plant, numbers, and productivity of potato tubers due to treatment with doses of NPK fertilizer at the age of 92 DAP

\begin{tabular}{|c|c|c|c|c|}
\hline $\begin{array}{c}\text { Treatment } \\
\text { Dosage }\end{array}$ & $\begin{array}{c}\text { weight of } \\
\text { fresh plant (g) }\end{array}$ & $\begin{array}{c}\text { weight of dry } \\
\text { plant (g) }\end{array}$ & $\begin{array}{c}\text { Tuber } \\
\text { Diameter (cm) }\end{array}$ & $\begin{array}{c}\text { Number of } \\
\text { Tubers (pieces) }\end{array}$ \\
\hline $\mathrm{P}_{0}(\mathrm{Kontrol})$ & $791,00^{\mathrm{ab}}$ & $181,00^{\mathrm{a}}$ & $5,16^{\mathrm{ab}}$ & $8,33^{\mathrm{a}}$ \\
\hline $\mathrm{P}_{1}(150 \mathrm{~kg} / \mathrm{ha})$ & $725,00^{\mathrm{a}}$ & $160,33^{\mathrm{a}}$ & $5,40^{\mathrm{ab}}$ & $7,67^{\mathrm{a}}$ \\
\hline $\mathrm{P}_{2}(300 \mathrm{~kg} / \mathrm{ha})$ & $741,67^{\mathrm{a}}$ & $206,25^{\mathrm{a}}$ & $5,25^{\mathrm{ab}}$ & $6,00^{\mathrm{a}}$ \\
\hline $\mathrm{P}_{3}(450 \mathrm{~kg} / \mathrm{ha})$ & $850,00^{\mathrm{b}}$ & $178,33^{\mathrm{a}}$ & $5,50^{\mathrm{b}}$ & $6,67^{\mathrm{a}}$ \\
\hline $\mathrm{P}_{4}(600 \mathrm{~kg} / \mathrm{ha})$ & $750,00^{\mathrm{ab}}$ & $141,67^{\mathrm{a}}$ & $5,29^{\mathrm{ab}}$ & $6,33^{\mathrm{a}}$ \\
\hline $\mathrm{P}_{5}(750 \mathrm{~kg} / \mathrm{ha})$ & $775,00^{\mathrm{ab}}$ & $134,5^{\mathrm{a}}$ & $4,9^{\mathrm{a}}$ & $9,33^{\mathrm{a}}$ \\
\hline $\mathrm{P}_{6}(900 \mathrm{~kg} / \mathrm{ha})$ & $766,67^{\mathrm{ab}}$ & $175,00^{\mathrm{a}}$ & $5,30^{\mathrm{ab}}$ & $10,67^{\mathrm{a}}$ \\
\hline
\end{tabular}

Notes: Numbers followed by the same letter in each variable showed no significant difference based on Duncan's test at $5 \%$ a level.

\subsection{Weight of fresh plant and tuber diameter}

The weight of fresh plant of potato plants is the weight of the plant when the plants are still alive and is weighed directly after harvest, before the plants wither due to water loss [12]. For the variable weight of fresh plant of Medians potato tubers at the age of 92 DAS which gave the best results was 850 grams treated with NPK fertilizer $450 \mathrm{~kg} \mathrm{ha}^{-1}$ (P3) the lowest yield was $725 \mathrm{~g}$ or on treatment $\mathrm{P}_{1}$. The same thing is also shown by the results of Adhikari's (2009) [12] research that NPK can increase tuber diameter and weight of fresh plant.

In Table 1, it can be seen that the fresh weight and diameter of the fruit gave the highest yield in the $\mathrm{P}_{3}$ treatment, which was $450 \mathrm{~kg} \mathrm{ha}^{-1}$ and decreased as the fertilizer dose increased. In this case, it shows that the higher the dose of fertilizer, it does not guarantee a significant increase in the growth and yield of potato plants (Table 2). Giving a high dose of fertilizer to a certain extent will cause the yield to increase, and concentrations that exceed the limit will show a decrease. Plants that are given excessive doses of fertilizer, no longer encourage growth to be more active but instead begin to suppress the rate of plant growth [13]. This is in line with the results of research on NPK on potato tuber diameter, namely increasing the dose of fertilizer reduces tuber diameter of potato plants and gives yields at $300 \mathrm{~kg} \mathrm{ha}^{-1}$ [14].

The accumulation of the amount of carbohydrates in the tubers affects the weight of fresh plant and tuber diameter. The more carbohydrates which can be translated into tubers, the more amka increases tuber weight [15]. The tuber diameter is formed from the accumulation of assimilating yields stored in tubers. This situation causes the tubers to experience an increase in tuber size and weight thus affecting the quality of tubers [14].

\subsection{Weight of dry plant}

Plant weight of dry plant reflects the accumulation of organic compounds which have been successfully synthesized by plants from organic compounds, especially water and carbon dioxide. Nutrients which have been absorbed by the roots contribute to the increase in weight of dry plant of plants [16]. NPK fertilizer contains potassium nutrients which will increase the growth and development of lateral roots, thereby affecting the ability of potato plants to 
absorb water. This causes potato plants with different treatments to absorb different amounts of water, which then evaporates during the drying process [17].

The weight of dry plant represents the accumulation of carbohydrates, proteins and vitamins and other organic materials. Doses of fertilizer $\mathrm{P}_{1}, \mathrm{P}_{2}, \mathrm{P}_{3}, \mathrm{P}_{4}, \mathrm{P}_{5}$ and $\mathrm{P}_{6}$ showed insignificantly different results. This shows that the accumulation of carbohydrates, proteins, vitamins and other organic materials between the control treatments is the same as those treated with other NPK fertilizers. The large size of potato tubers is not an indication that the content of organic compounds in the tubers such as carbohydrates, proteins, lipids and other organic compounds from metabolic processes is also large, but there may be a large water content so that the weight of dry plant of potato tubers produced does not differ between treatments (Table 1).

In addition, the weight of dry plant of the plant which was not significantly different might be due to the low $\mathrm{N}$ nutrient in the soil. Because $\mathrm{N}$ is an element which plants need in large quantities, but its presence in the soil is very mobile so that it is easily lost from the soil through washing or evaporation [18]. Lack of $\mathrm{N}$ will result in a decrease in plant weight of dry plant, leaf area, thereby reducing the rate of photosynthesis $[19,20]$.

\subsection{Crop productivity}

Effect of fertilizer treatments on crop productivity are presented on Table 2. The Duncan Test analysis was 5\% and showed that the treatment of NPK fertilizer at various dosage had a significant effect on crop productivity.

Table 2. Median potato crop productivity at 92 DAP

\begin{tabular}{|c|c|c|}
\hline No & Dosage / Treatment & $\begin{array}{c}\text { Crop Productivity } \\
\text { (ton }^{-1} \mathbf{h}^{-1}\end{array}$ \\
\hline 1 & $\mathrm{P}_{0}($ Kontrol) & $10,33^{\mathrm{ab}}$ \\
\hline 2 & $\mathrm{P}_{1}(150 \mathrm{~kg} / \mathrm{ha})$ & $9,67^{\mathrm{ab}}$ \\
\hline 3 & $\mathrm{P}_{2}(300 \mathrm{~kg} / \mathrm{ha})$ & $14,00^{\mathrm{ab}}$ \\
\hline 4 & $\mathrm{P}_{3}(450 \mathrm{~kg} / \mathrm{ha})$ & $18,33^{\mathrm{b}}$ \\
\hline 5 & $\mathrm{P}_{4}(600 \mathrm{~kg} / \mathrm{ha})$ & $8,33^{\mathrm{a}}$ \\
\hline 6 & $\mathrm{P}_{5}(750 \mathrm{~kg} / \mathrm{ha})$ & $10,33^{\mathrm{ab}}$ \\
\hline 7 & $\mathrm{P}_{6}(900 \mathrm{~kg} / \mathrm{ha})$ & $14,67^{\mathrm{ab}}$ \\
\hline
\end{tabular}

Notes: Numbers followed by the same letter in each variable showed no significant difference based on Duncan's test at $5 \% \alpha$ level.

Data on Table 2 shows that the incease of NPK dosage was not followed by the increase of crop productivity. The highest crop productivity (18.33 ton/ha) was reached on $45 \mathrm{~kg} \mathrm{NP}$ fertilizer per ha. Potato plants need macro nutrients or nutrients $\mathrm{N}, \mathrm{P}, \mathrm{K}, \mathrm{S}, \mathrm{Mg}, \mathrm{Ca}$ and micro nutrients $\mathrm{Mo}, \mathrm{Cu}, \mathrm{B}, \mathrm{Zn}, \mathrm{Fe}$, and $\mathrm{Mn}$. Nutrients which greatly affect potato productivity are the elements N, P and K [21]. These nutrients are obtained from the soil and through NPK fertilization is an effort to add NPK macro nutrients to the soil in the hope that other nutrients will be available in the soil [22].

Plants need adequate nutrition for potatoes to achieve optimum yields [23,24]. The results showed that the highest potato yields were obtained with fertilizer doses of $415 \mathrm{~kg} \mathrm{NPK} \mathrm{ha}^{-1}$ $[25,26], 422.47$, and $520 \mathrm{~kg} \mathrm{NPK} \mathrm{ha}^{-1}$ [23]. This is in accordance with the results of the study which found that at a dose of $450 \mathrm{~kg} \mathrm{ha}^{-1}$, it gave the highest results compared to other doses. However, it can be seen that as the dose increases, the results decrease. This is in accordance with Liebig's Minimum Law where the addition of elements made above the point limit cannot help because other elements become limiting factors [27]. So that at $\mathrm{P}_{4}$ it has reached its maximum point and has decreased at $\mathrm{P}_{4}-\mathrm{P}_{6}$. 
In addition, another possibility that causes a higher dose of fertilization, indicating a decrease in yield, is because the NPK compound fertilizer reacts sourly, causing a decrease in soil $\mathrm{pH}$. These conditions do not support the growth of potato plants [28].

The use of NPK is up to a dose of $900 \mathrm{~kg} \mathrm{ha}^{-1}$ because that dose is the dose that farmers use. There are even research results that state that offering NPK $1000 \mathrm{~kg} \mathrm{ha}^{-1}$ gives the highest results [29]. By comparing with the results of the study, $450 \mathrm{~kg} \mathrm{ha}^{-1}$ is the right dose for farmers to give. So that farmers can reduce the use of NPK fertilizers.

\section{Conclusion}

The NPK fertilizer applied for potato cultivation has significantly affected potato productivity. The highest potato productivity of $18.33 \mathrm{ton} /$ ha was reached with $450 \mathrm{~kg}$ NPK $\mathrm{ha}^{-1}$.

\section{References}

1. Badan Pusat Statistik, Produksi tanaman sayuran, Available at: https://www.bps.go.id/indicator/55/61/1/produksi-tanaman-sayuran.html (BPS, Jakarta, 2020)

2. Salwati, Handoko, I. Las, Hidayati, Inform. Pertan. 22, 1, 53 - 64 (2013)

3. A.J. Tiyas, P, Henik, P. Saptya, J. Agribest. 2, 2, 131-146 (2018)

4. H.K. Ridwan, Nurmalinda, Sabari, Y. Hilman, J. Hortik. 20, 2, 196-206 (2010)

5. A. Rosyidah, Folium. J. Ilmu Pertan. 1, 1, 80-89 (2017)

6. R.W. Allard, Principles of Plant Breeding (John Wiley and sons, New York, 1989)

7. A. Kiloes, Puspitasari, Analisis stakeholders dalam pengembangan varietas kentang olahan, in Prosiding Kongres Teknologi Nasional 2016, PuslitbangHorti Cimanggu (2016)

8. A.M.A. Moshileh, M.A. Errebhi, M.I. Motawei, J. Agric Sci. 17, 1, 1-9 (2005)

9. L.B. Rakočević, Z. Dinic, G. Dugalić, M. Dugalić, J. Mladenović, M. Đurić, Acta Agric. Serbica. 13, 45, 101-1101 (2018)

10. B.H. Buntoro, R. Rogomulyo, S. Trisnowati, Vegetalika. 3, 4, 29-39 (2014)

11. E. Kaya, Agrologia. 2, 1 (2013)

12. R.C. Adhikari, Nepal Agric. Res. J. 9, 67-75 (2009)

13. Kuruseng, Hamzah, J. Agrisistem. 7, 1 (2011)

14. Anggun, Supriyono, J. Syamsiyah, Agrotech. Res. J. 1, 2, 33-38 (2017)

15. R. Suryaningrum, E. Purwanto, Sumiyati, Agrosains. 18, 2, 33-37 (2016)

16. G.D. Nainggolan, Suwardi, Darmawan, J. Zeolit Indones. 8, 2, 89-96 (2009)

17. S. Parman, Bul. Anat. dan Fisiol. 15, 2 (2007)

18. A. Marouani, O. Behi, H.B.H. Salah, O.A. Quilez, Com. Soil Sci. Plant Anal. 46, 4, 476$489(2015)$

19. W. Li, B. Xiong, S. Wang, X. Deng, L. Yin, H. Li, PloS one. 11, 1, e0146877 (2016)

20. F. Djufry, Nurjanani, Ramlan, J. Pengkaj. dan Pengemb. Teknol. Pertan. 17, 2, 115-124 (2014)

21. A. Damari, Alfayanti, Yartiwi, Farming analysis of red potato with various dose of fertilizer in highland, in Proceeding ISEPROLOCAL, Badan Penerbitan Fakultas Pertanian Universitas Bengkulu, Bengkulu, Indonesia (2015)

22. N. Sutrisna, Y. Surdianto, J. Hort. 24, 2, 124-132 (2014)

23. N.K. Fageria, V.C. Baligar, C.A. Jones, Growth and Mineral Nutrition of Field Crops 3 Edition (CRC Press, New York, 2011)

24. Vita, Potatoes in Development: A Model of Collaboration for Farmers in Africa (2015) 
25. S.P. Trehan, Potato J. 36, 3-4 (2009)

26. M. Nityamanjari, Int. J. Agric. Sci. 10, 4, 5183-5186 (2018)

27. Munawar, Kesuburan tanah dan nutrsi tanaman (IPB Press, Bogor, 2011)

28. A.D. Suyono, T. Kurniatin, S. Mariam, M. Damayani, T. Syammusa, A. Yuniarti, E. Trinurani, Y. Machfud, Pupuk dan pemupukan (Unpad Press, Jawa Barat, 2008)

29. Y. Yusdian, E. Kantikowati, R. Yanto, J. AgroTatanen. 2, 1, 27-35 (2019) 